\title{
Definition and classification system of glacial lake for inventory and hazards study
}

\author{
YAO Xiaojun ${ }^{1}$, LIU Shiyin ${ }^{2,3,4}$, HAN Lei ${ }^{5}$, SUN Meiping ${ }^{1,4}$, ZHAO Linlin ${ }^{1,4}$ \\ 1. College of Geography and Environment Sciences, Northwest Normal University, Lanzhou 730070, China; \\ 2. Yunnan Key Laboratory of International Rivers and Transboundary Eco-security, Kunming 650500, China; \\ 3. Institute of International Rivers and Eco-Security, Yunnan University, Kunming 650091, China; \\ 4. State Key Laboratory of Cryosphere Sciences, Northwest Institute of Eco-Environment and Resources, \\ CAS, Lanzhou 730000, China; \\ 5. Geological Survey Institute of Sichuan Province, Chengdu 610081, China
}

\begin{abstract}
Glacial lakes are not only the important refresh water resources in alpine region, but also act as a trigger of many glacial hazards such as glacial lake outburst flood (GLOF) and debris flow. Therefore, glacial lakes play an important role on the cryosphere, climate change and alpine hazards. In this paper, the issues of glacial lake were systematically discussed, then from the view of glacial lake inventory and glacial lake hazards study, the glacial lake was defined as natural water mainly supplied by modern glacial meltwater or formed in glacier moraine's depression. Furthermore, a complete classification system of glacial lake was proposed based on its formation mechanism, topographic feature and geographical position. Glacial lakes were classified as 6 classes and 8 subclasses, i.e., glacial erosion lake (including cirque lake, glacial valley lake and other glacial erosion lake), moraine-dammed lake (including end moraine-dammed lake, lateral moraine-dammed lake and moraine thaw lake), ice-blocked lake (including advancing glacier-blocked lake and other glacier-blocked lake), supraglacial lake, subglacial lake and other glacial lake. Meanwhile, some corresponding features exhibiting on remote sensing image and quantitative indices for identifying different glacial lake types were proposed in order to build a universal and operational classification system of glacial lake.
\end{abstract}

Keywords: glacial lake; glacier; definition; classification; inventory; hazard

\section{Introduction}

Lakes refer to water bodies which are formed in land surface basin or waterlogged depression, having certain water area and water exchange being relatively slow (Ma et al., 2011). Lakes are not only the important component of the Earth's hydrosphere, but also can faithfully record the regional climate change in different time scales and human activities around

Received: 2017-04-23 Accepted: 2017-06-05

Foundation: National Natural Science Foundation of China, No.41261016, No.41561016; Opening Foundation Projection of State Key Laboratory of Cryosphere Sciences, CAS, No.SKLCS-OP-2016-10; Youth Scholar Scientific Capability Promoting Project of Northwest Normal University, No.NWNU-LKQN-14-4; Geological Survey Project of China Geological Survey, No.DD2016034206

Author: Yao Xiaojun (1980-), PhD and Associate Professor, specialized in the research of GIS and cryospheric change. E-mail: xj_yao@nwnu.edu.cn 
lake. So lake is often considered as an important information carrier to reveal global climate change and the regional response (Cenderelli and Wohl, 2001; Ding et al., 2006; Yao et al., 2014; Liu et al., 2014). Glacial lakes, as one of the lake types, are precious fresh water resources and the natural landscape in alpine region, and yet act as a trigger of many glacial hazards (Richardson and Reynolds, 2000; Wang et al., 2010). Under the background of global warming, glacier-related hazards such as glacial lake outburst flood (GLOF) and debris flow presented an increase tendency in amount and harmful intensity (Cui et al., 2014). In the Tibetan Plateau, for example, there had been at least 28 GLOF events since the 1930s (Sun et al., 2014; Yao et al., 2014), and had characteristics of frequency increase and temporal extension after 2000. Therefore, glacial lakes have attracted widespread attention from the academia and local government (Cui et al., 2014).

Globally, glacial lakes are mainly located in North America (e.g. Rocky Mountains and Coastal Mountains of Alaska, USA) (O’Connor and Costa, 1993; Clague and Evans, 2000), South America (e.g. Andes Mountains) (Carey, 2005), Europe (e.g. Iceland, the Alps and Caucasus) (Huggel et al., 2002; Björnsson, 2003; Stokes et al., 2007; Emmer et al., 2015), and Asia (e.g. Altay Mountains, Tianshan Mountains, Karakoram Range, the Himalayas) (Fujita et al., 2008; Chen et al., 2010; Janský et al., 2010; Li et al., 2011; Engel et al., 2012; Wang et al., 2012; Wang et al., 2013; Wang et al., 2016; Song et al., 2016; Song et al., 2017). The interest area of glacial lakes in China was mainly concentrated in the Himalayas (Gao et al., 2015; Liao et al., 2015), Tianshan Mountains (Wang et al., 2013), Karakoram Range (Wortmann et al., 2014), Altay Mountains (Chen et al., 2015) and southeastern Tibet (Wang et al., 2012; Song et al., 2016). And these studies focused on the change of glacial lakes (Liu et al., 2011; Wang et al., 2013; Gao et al., 2015; Song et al., 2016; Wang et al., 2016), the identification of potential dangerous glacial lakes (Cao et al., 2016; Liu et al., 2016), and the simulation of GLOFs (Le et al., 2014). In recent years, the inventory of glacial lakes in some mountainous regions had been carried out based on multi-source remote sensing images by scholars and institutions. For instance, Wang et al. (2010) and Pradeep et al. (2001) digitalized the glacial lakes in the Hindu Kush-Himalaya Range, respectively. These datasets had been an important basis for recognizing the spatial-temporal characteristics of glacial lakes change and understanding the response of glacial lakes to the climate change in this region. However, there is still great controversy about the definition and classification system of glacial lakes, which will directly lead to some difficulties for comparing the result from different researches. Some conclusions of glacial lakes change were even opposite. For example, Gao et al. (2015) and Wang et al. (2014) analyzed the glacial lakes change in the Koshi River basin from 2000 to 2010, the former believed that both number and area of glacial lakes were increasing, but the latter thought that the number was decreasing and yet the area was increasing. Even more puzzling was the fact that, the remote sensing images in 2000 used in the two studies above were the same, with the number of glacial lakes being 1228 and 1680 , respectively. Therefore, it is necessary and urgent to accurately define glacial lakes, to build a complete classification system of glacial lakes and to provide corresponding features for remote sensing identification.

\section{Glacial lake}

In the Glossary of Cryospheric Science (Qin et al., 2016), glacial lake is defined as lake 
formed by glaciation. In the Wikipedia Encyclopedia (https://en.wikipedia.org), a glacial lake is a lake with origins in a melted glacier. They are formed when a glacier erodes the land, and then melts, filling the hole or space that it has created. Lü et al. (1999) thought that a glacial lake was a natural water body similar to artificial reservoir formed by ancient or modern glaciers. Additionally, there are many similar definitions of glacial lake: (1) glacial lake is one kind of lake formed by glaciation or supplied by glacial meltwater (Cao et al., 2016); (2) glacial lake is plateau lake located at the terminus or the lateral part of one glacier and glacier provides water resource when it retreats or melts (Tang et al., 2014); (3) glacial lakes were located in a basin formed by alpine glacier movement since the Last Glaciation Maximum (LGM), and their water were mainly from modern glacial meltwater or atmospheric precipitation (Chen et al., 2015). In these definitions of glacial lake above, it is emphasized that glacial lakes are formed by glaciation. The main differences are whether the time information being given or not and the material source of glacial lakes. The discrepancy of accepted concept of glacial lake caused that it was difficult to separate glacial lakes from natural lakes, which was particularly obvious in the inventory of glacial lakes and the change researches afterwards. Instead, the lakes in a specified distance of glaciers were treated as glacial lakes by scholars. For instance, Wang et al. (2013) and Zhang et al. (2015) selected lakes in a $10 \mathrm{~km}$ buffer of glaciers as glacial lakes in the Tianshan Mountains and Tibetan Plateau. However, it is debatable that these lakes selected are whether supplied by glacial meltwater or there are other lakes formed by glaciation beyond the specified extent. Undoubtedly, glacial meltwater is the main material source of glacial lakes as these definitions above mentioned. But it is very difficult to quantify the glacial meltwater and calculate its proportion in lake water volume in reality. If one lake receives glacial meltwater but is distant from the glacier, or the glacier supplied lake disappears, it is also one problem to judge whether these lakes are glacial lakes or not. These challenges had been causing that some research results of glacial lakes were not comparable; meanwhile, it was also difficult to share dataset of glacial lakes among different organizations.

From the mechanism of glacial lake formation, glacial lakes are generated in erosion depressions caused by glaciers advance and retreat, and then receive glacial meltwater and precipitation. That is to say, glaciation is the dominant factor in the formation of glacial lakes. The LGM is the latest glaciation period when glacier coverage was the largest on the Earth. Theoretically, a glacial lake can be defined as the natural water body formed in the depression by glaciation since the LGM. However, there are still many problems and controversies in this definition of glacial lake. One thorny issue is the determination of the coverage extent of glaciers in the LGM. The other is whether the great lakes over the Tibetan Plateau such as Namco, Yamzho Yumco Lake are glacial lakes or not. Recently, the studies of glacial lake were mainly focused on the following fields: the inventory of glacial lakes based on remote sensing images, the response of glacial lakes to modern climate change, the coupling relationship between glacier variation and glacial lake evolution, the identification of dangerous glacial lakes and glacial lake outburst flood/debris flow disasters, etc. On the one hand, the focus of these studies is modern evolution processes of glacial lakes in the temporal dimension, and on the other hand they all emphasized the role of modern glaciers on the formation and evolution of glacial lakes. Therefore, in view of the modern process and practical application, glacial lakes can be defined as natural water mainly supplied by 
modern glacial meltwater or formed in glacier moraine's depression. In the latter definition of glacial lake, it is emphasized on the role of modern glaciers in the formation and change of glacial lakes. For the inventory or digitalization of glacial lakes in one region, it is suggested that the glacier dataset including the WGI, the First and Second Chinese Glacier Inventory can be selected as the foundation of modern glaciers. To be sure, the classification system of glacial lakes in the next section is based on the latter definition of glacial lake.

\section{Classification system of glacial lake}

Internationally, there has been so far no accepted standard for the classification system of glacial lakes. Some organizations and scholars proposed the different classification systems of glacial lakes according to their own research purposes. In the inventory of glacial lakes in the Hindu Kush-Himalayan region, ICIMOD (Pradeep et al., 2001) divided the glacial lakes into 5 classes: glacial erosion lake, moraine-dammed lake, ice-blocked lake, supraglacial lake and subglacial lake. Based on this classification schema, Wu et al. (2011) proposed a detailed classification system including 3 classes and 10 subclasses. In the study of glacial lakes in the Altay Mountains, Yi and Cui (1994) suggested a multiple classification schema. According to the mechanical and thermal differences in the formation of glacial lakes, they were classified as glacial erosion lake, ice-blocked lake, moraine-dammed lake, glacial thaw lake and glacial composite lake. According to the water supply of glacial lakes, they were divided into ice-water lake and non-ice-water lake; the former were mainly supplied by glacial meltwater and the latter were dominated by surface runoff from atmospheric precipitation. In the inventory of glacial lakes in the Chinese Himalayas, Wang et al. (2010) presented a classification system including moraine-dammed lake, ice-blocked lake, cirque lake, glacial erosion lake, landslide-dammed lake, supraglacial lake and glacial valley lake. Cao et al. (2016) adopted a classification system including 3 classes and 6 subclasses: glacial erosion lake (including cirque lake and other glacial erosion lake), moraine-dammed lake (including end moraine-dammed lake, lateral moraine-dammed lake and other moraine-dammed lake) and supraglacial lake. Additionally, Wang et al. (2016) proposed an integrated classification schema of glacial lakes according to the formation age of glacial lakes, the properties of dam, the shape of lake basin, the water supply, the area change, the spatial relation between glacial lake and its supply glacier, the risk level, etc. But there was a defect of disagreement between the actual glacial lakes classification and the theoretical classification system. On the basis of previous researches and the principles of systematic, normalization, operability and scalability, we proposed a complete classification schema of glacial lakes including 6 classes: glacial erosion lake, moraine-dammed lake, ice-blocked lake, supraglacial lake, subglacial lake and other glacial lake (Table 1). According to the position or geomorphologic characteristics of glacial lakes, the first 3 classes can be divided into 8 subclasses: cirque lake, glacial valley lake, other glacial erosion lake, end moraine-dammed lake, lateral moraine-dammed lake, moraine thaw lake, advancing glacier-blocked lake and other glacier-blocked lake.

Due to the wide application of satellite remote sensing images in the inventory of glacial lakes and studies of their changes, the interpretation characteristics of different types of glacial lakes are given in the following. Before the interpretation of glacial lake types, it is noted that researchers should firstly determine the approximate distribution of glacial lakes based on the inventory of glaciers and digital elevation model (DEM) data; that is to say, 
lakes are only considered in the basin of modern glaciers. Meanwhile, although the lake is easily identified because of the obvious differences in the spectral characteristics of water body and its surrounding features in remote sensing images, it is very difficult to distinguish the types of glacial lakes scarcely by a single sensor or mono-phase remote sensing image. So other data sources and technologies should be needed, too. For instance, DEM data can be used to produce the mountain shadow so as to remove the wrong interpretation of glacial lakes; 3D visualization technology such as the Google Earth and high-resolution remote sensing images can be integrated to distinguish the type of glacial lakes.

Table 1 The classification system of glacial lakes

\begin{tabular}{|c|c|c|}
\hline Class & Subclass & Description \\
\hline \multirow{3}{*}{$\begin{array}{l}\text { Glacial erosion } \\
\text { lake }\end{array}$} & Cirque lake & The lake in one cirque \\
\hline & Glacial valley lake & The lake in U-shaped valley by glaciation \\
\hline & Other glacial erosion lake & $\begin{array}{l}\text { The lake formed by glacier erosion but not belonged to other } \\
\text { classes of glacial lake }\end{array}$ \\
\hline \multirow{3}{*}{$\begin{array}{l}\text { Moraine-dammed } \\
\text { lake }\end{array}$} & End moraine-dammed lake & The lake between the end moraine ridge and glacier terminus \\
\hline & Lateral moraine-dammed lake & The lake beside the lateral moraine ridge \\
\hline & Moraine thaw lake & The lake on the moraine ridge \\
\hline \multirow{2}{*}{ Ice-blocked lake } & Advancing glacier-blocked lake & The lake blocked by advancing glacier \\
\hline & Other glacier-blocked lake & The lake with the dam being glacier ice \\
\hline Supraglacial lake & & The lake on the surface of glacier \\
\hline Subglacial lake & & The lake within the glacier or over the glacier bed \\
\hline Other glacial lake & & The lake blocked by landslide, avalanche, debris flow, etc. \\
\hline
\end{tabular}

\subsection{Glacial erosion lake}

Glacial erosion lake refers to the water body in the depression formed by erosion and abrasion of glacier in the process of glacier movement. At present, the common glacial erosion lakes were mostly formed by erosion of Quaternary glaciers. These glacial lakes were mainly supplied by atmospheric precipitation and had few modern glaciers in their upper part. As mentioned above, if no modern glaciers exist in the upper lakes, these lakes will not belong to glacial lakes. That is to say, ancient glacial erosion lakes should not be considered. According to the location and geomorphologic characteristics of glacial erosion lakes, they can be divided into the following 3 subclasses.

\subsubsection{Cirque lake}

The outstanding feature of the cirque lake is that it is located in the cirque. The typical cirque is like an arm-chair surrounded by three steep rock walls and a high reverse rock sill (see Figure 1, the centroid coordinates of the lake are $29^{\circ} 42^{\prime} 18^{\prime \prime} \mathrm{N}, 96^{\circ} 18^{\prime} 32^{\prime \prime} \mathrm{E}$ ). Cirque lakes are usually small and near the equilibrium-line altitude (ELA) of glaciers. In the identification of cirque lake based on remote sensing images, it is necessary to use slope data derived from DEM data or Google Earth software to check the consistency between terrain features of glacial lakes and the cirque. If its terrain features satisfy the shape of the cirque, glacial lakes can be classified into cirque lake.

\subsubsection{Glacial valley lake}

Large glaciers usually formed a U-shaped valley being steep and straight on both sides and 
flat at the bottom by laterally eroding in tributary and downward eroding on the glacier bed. Glacial meltwater and atmospheric precipitation flowed into the valley and then constituted a lake, namely glacial valley lake. This kind of glacial lakes were usually larger and far from modern glaciers. In order to expediently distinguish with moraine-dammed lakes since the Little Ice Age (LIA) and consider their potential danger on the downstream areas, some lakes in alpine region could been classified into glacial valley lake. According to the distance from the Akkol Lake to its

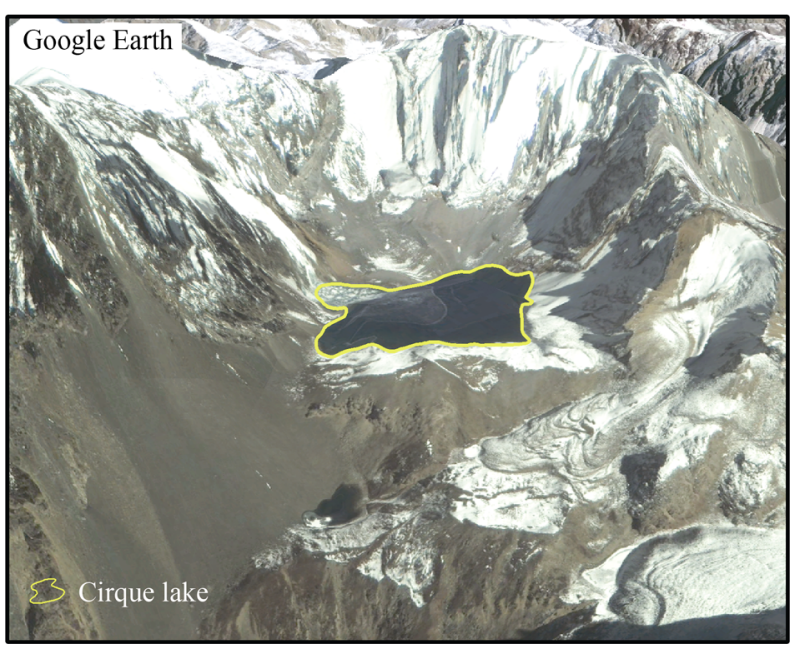

Figure 1 Cirque lake supply glacier (Kanas Glacier) in the Altay Mountains and the area of Kanas Glacier (Figure 2 ), it is suggested that the identification of glacial valley lake can be based on the following criteria: (1) the morphology of lake should be U shaped; (2) there should be large glacier with an area of above $20 \mathrm{~km}^{2}$ in the upper lake; (3) the distance from lake to its supply glacier should be less than $15 \mathrm{~km}$ so as to distinguish with tectonic lakes.

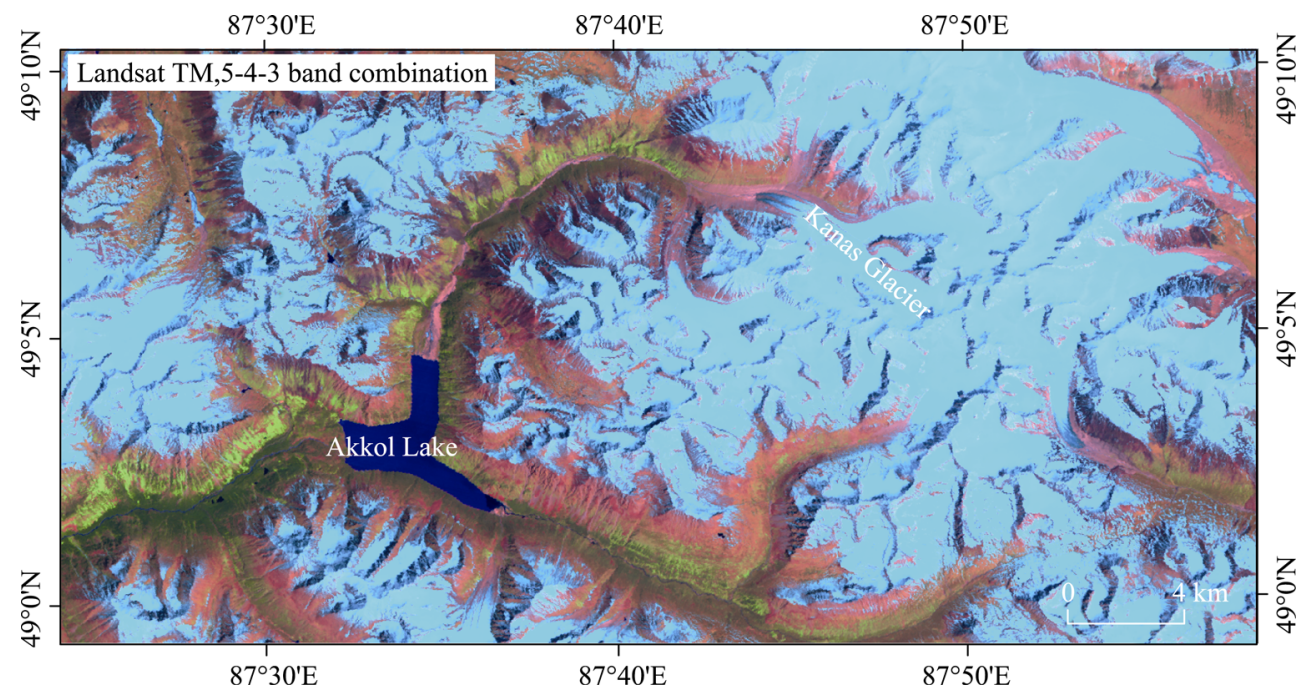

Figure 2 Glacial valley lake

\subsubsection{Other glacial erosion lake}

Glacial lakes formed by glacier erosion, which are difficult to be identified by morphological features and do not belong to the other types describing in the flowing, can be classified as other glacial erosion lake.

\subsection{Moraine-dammed lake}

Moraine-dammed lake is a water body between moraine ridge and glacier due to the ob- 
struction of moraine ridge. According to the location, moraine-dammed lakes can be divided into 3 subclasses: end moraine-dammed lake, lateral moraine-dammed lake and moraine thaw lake.

\subsubsection{End moraine-dammed lake}

When glacier retreats, glacial meltwater accumulated in the space between glacier terminus and end moraine ridge, then formed a lake, namely end moraine-dammed lake. This kind of moraine-dammed lake is the main type causing glacial lake outburst flood or debris flow in the Himalayas and Nyainqentanglha Mountains. End moraine-dammed lakes are usually easy to distinguish in the remote sensing image because they are mostly linked to glacier terminus or the distance between them is very small (Figure 3a). In addition, the end moraine ridge uplifting is clear in the Google Earth software (Figure 3b), which can help to identify the end moraine-dammed lake, too. In the downstream of larger glacier terminus, there are usually several end moraine ridges and some lakes are formed among them. These lakes are mainly supplied by glacial meltwater and are formed by glaciation, so they can be classified as end moraine-dammed lake. Based on the measurement among these lakes in the Himalayas, the distance between the upper and the lower end moraine-dammed lakes is less than $2.0 \mathrm{~km}$. In other words, the lakes with a distance being far from the upper end moraine-dammed lake than $2.0 \mathrm{~km}$ should be not identified as end moraine-dammed lake.
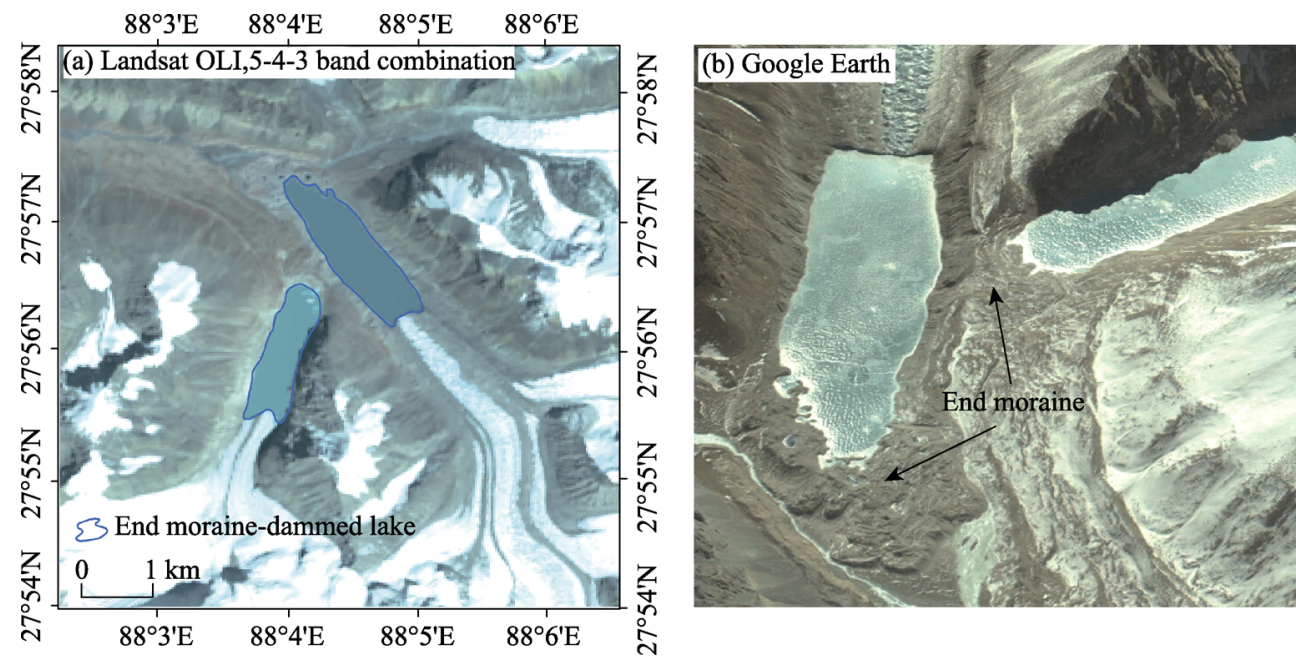

Figure 3 End moraine-dammed lake

\subsubsection{Lateral moraine-dammed lake}

Lateral moraine-dammed lake refers to the water body beside the lateral moraine ridge of glacier. These glacial lakes usually appear around the larger valley glacier and are formed by main valley glacier blocking the meltwater of tributary valley glacier. For instance, there are 5 lateral moraine-dammed lakes beside the Ngozumpa Glacier which is the largest glacier in the southern Mount Everest (Figure 4), and the third Gokyo Lake with an area of $0.59 \mathrm{~km}^{2}$ is the biggest one.

\subsubsection{Moraine thaw lake}

In the end/lateral moraine ridge of glacier, there are usually many but small ponds (Figure 5), 
which are named as glacial thaw lake or moraine-dammed lake (Yi and Cui, 1994; Wang et al., 2016). The principal agent controlling these lakes is freeze-thaw process. For example, dead ice within the moraine ridge melts due to the temperature rising, and then the surface sinks and forms the depression retaining water. Although these ponds do not receive glacial meltwater but are formed by the dead ice meltwater of glacier, they can be classified as glacial lakes, namely moraine thaw lake. It should be pointed out that thaw lakes widely distributed in rock glacier and frozen ground region do not belong to moraine thaw lake, and they should be

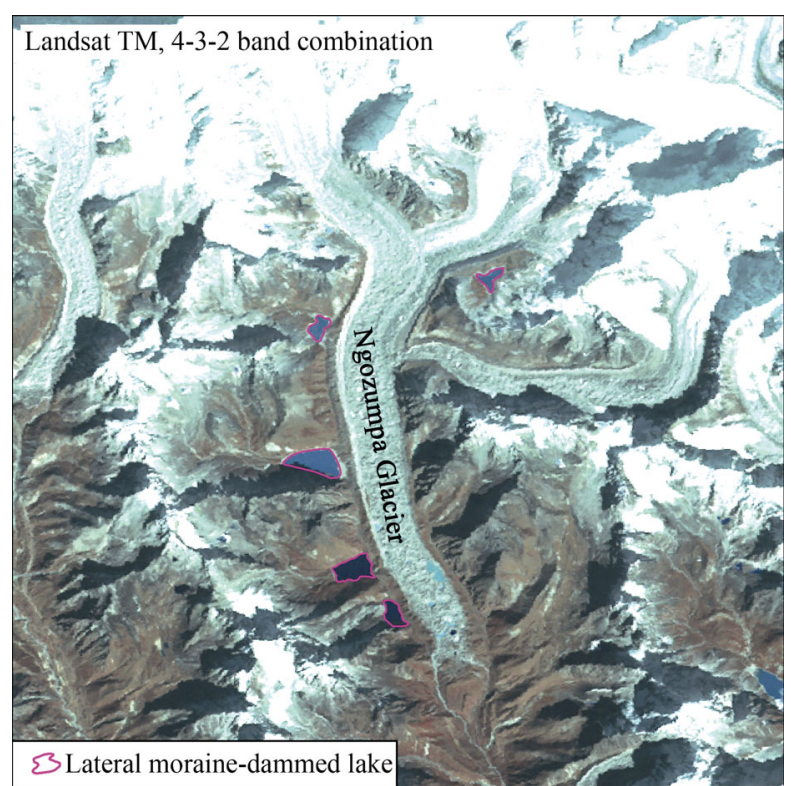

Figure 4 Lateral moraine-dammed lake eliminated in the inventory of glacial lakes.

\subsection{Ice-blocked lake}

Whether the glacier advanced and blocked the valley or the branch glacier rapidly retreated and was separated from the main glacier, they all resulted in the water accumulation, and then formed a lake. The common feature of these lakes is that their dams are composed of glacier ice, so they can be named as ice-blocked lake. According to their forming mechanism, ice-blocked lakes can be divided into advancing glacier-blocked lake and other glacier-blocked lake. The representation of the former is Kyagar Thso Lake located in the Yarkant River basin in China (Zhang et al., 1989; Wang et al., 2009). An example of the latter is Merzbacher Lake near the South Inylchek Glacier in Kyrgyzstan (Liu et al., 1998; Shen et al., 2009). Other glacier-blocked lakes also exist in the interior of the Tibetan

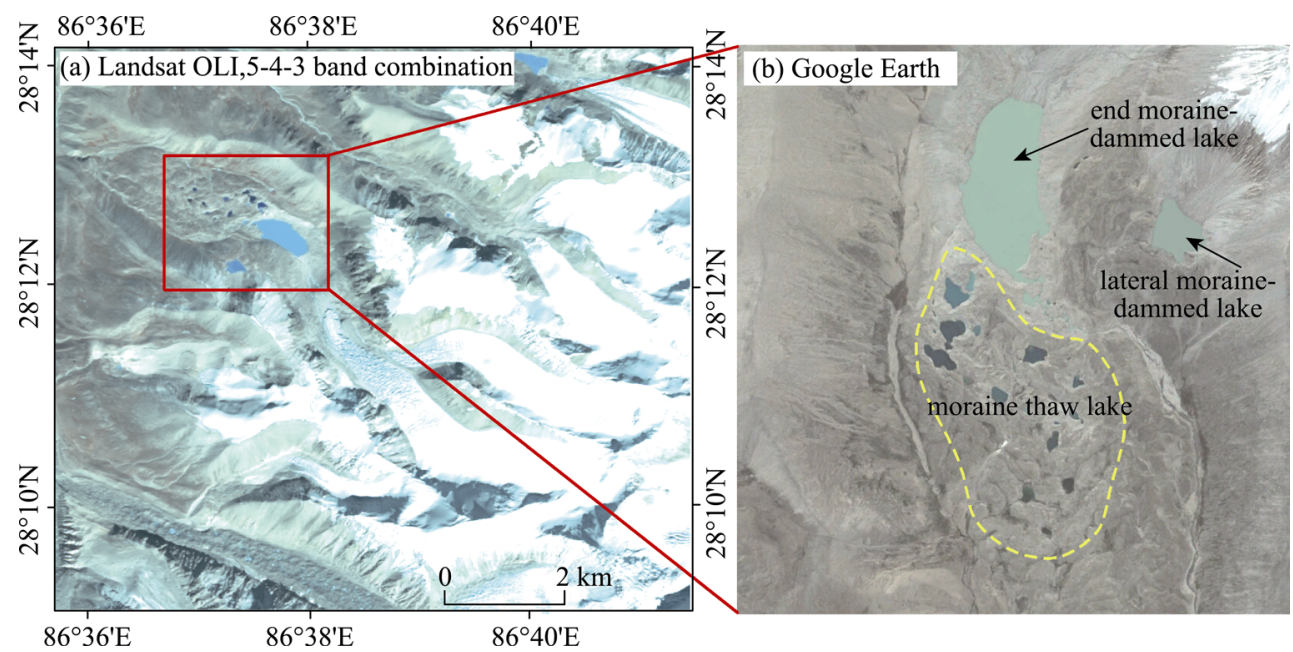

Figure 5 Moraine thaw lake (water body in blue-green color within the yellow-color polygon in (b) 


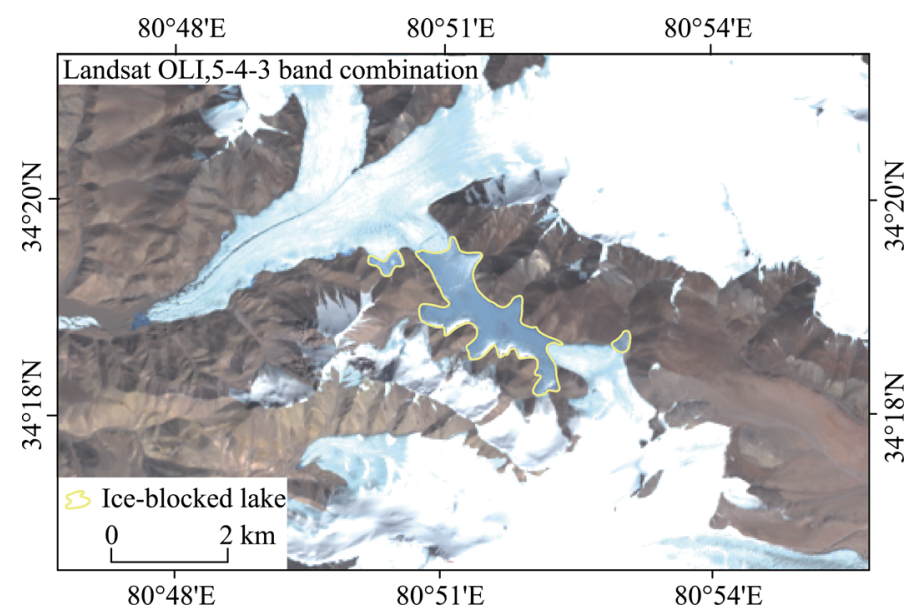

Figure 6 Ice-blocked lake over the Tibetan Plateau

Plateau (Figure 6), which has not been previously reported. For advancing glacier-blocked lakes, they usually survived for a few months to one year affected by temperature increase in low altitude and lake water erosion (Wang et al., 2009). For other glacier-blocked lakes, their evolution presented different characteristics. For example, Merzbacher Lake outburst floods mostly occurred in July - September and caused 50 GLOF events from 1932 to 1997 (Liu et al., 1998), showing a life cycle of glacier-blocked lake to some extent. But for glacier-blocked lakes in the interior of the Tibetan Plateau, they are usually stable.

\subsection{Supraglacial lake}

Supraglacial lake refers to the water body on the surface of glacier due to different ablation. These lakes usually appear on the surface of ablation zone of debris-covered glaciers. As seen in Figure 7, there are many supraglacial lakes in Rongbuk Glacier on the northern Mount Everest, the largest of which had an area of $0.47 \mathrm{~km}^{2}$ in 2016 . In Tomur region of Tianshan Mountains, there are also many supraglacial lakes in some debris-covered glaciers, such as Tomur Glacier, Tugaibieliqi Glacier, Qong Terang Glacier, Koxkar Baxi Glacier, etc. When supraglacial lakes are connected with the drainage system inside the glacier, the lake water can be quickly exhausted. So supraglacial lakes change rapidly in annual and inter-annual scales. In view of the spatial resolution of Landsat TM/ETM+/OLI remote sensing images widely used, the quick variation of supraglacial lake, and being the origin of moraine-dammed lake (Richardson and Reynolds, 2000), it is suggested that the supraglacial lake with an area of above $0.02 \mathrm{~km}^{2}$ can be collected in the inventory of glacial lakes. The main difference between supraglacial lake and moraine thaw lake is their locations: the former is located on the surface of glacier; the latter is located on the moraine ridge of glacier.

\subsection{Subglacial lake}

The water body within the glacier can be named as subglacial lake. It had been found that there were more than 140 subglacial lakes under the Antartic ice sheet, the largest one was the Vostok Lake (Wingham et al., 2006). For alpine glaciers, lakes like subglacial lake had not been reported until now. However, small supraglacial lakes possibly exist in the distribution region of maritime glaciers such as southeastern Tibetan Plateau, because the drainage 


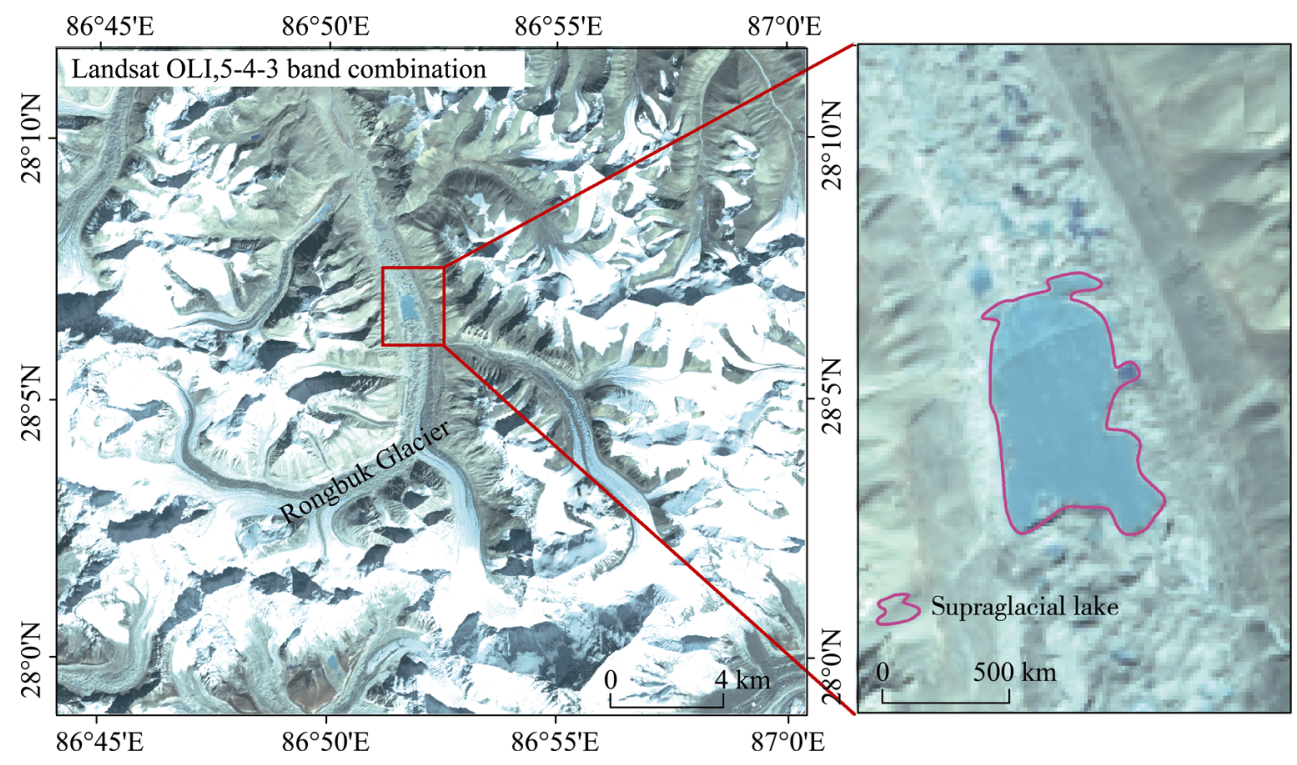

Figure 7 Supraglacial lake

channels under the glacier are well developed. It is impossible to identify subglacial lake only relying on satellite remote sensing image, other instrument like ground penetrating radar (GPR) is needed. For building a complete classification system of glacial lake, subglacial lake is listed, but it can be removed in the inventory of glacial lakes based on satellite remote sensing images.

\subsection{Other glacial lake}

Except for 5 classes of glacial lake mentioned above, the water body formed by landslide, rock collapse, avalanche and debris flow blocking the valley in the glaciation area is named as other glacial lake. This kind of lake belongs to dammed lake and has a great potential harm to the downstream settlements, roads, hydropower stations and other infrastructures. Therefore, it should be taken into account in the inventory of glacial lakes. The first basis for identifying the other glacial lake is its dam which can be examined from the high-resolution remote sensing images. The second is that the appearance of the other glacial lake is usually related to the earthquake, debris flow and other geologic activities, and there is an obvious change of lake size around the time. For instance, the debris flow caused by Ranzeria Co Lake outburst formed two glacial lakes in Jiali County (Sun et al., 2014). The quantitative index of identifying the other glacial lake is suggested that the distance from the glacier terminus is below $10 \mathrm{~km}$ (Wang et al., 2013; Zhang et al., 2015).

\section{Conclusions}

As an important object of the cryospheric science, glacial lakes are not only closely related to the climate change and glacier movement, but also play a role on mountain disaster chain. Therefore, glacial lakes had been paid more and more attentions by many scientists and governments. In this paper, the definition of glacial lake was comprehensively discussed. It was noted that the definition was based on two perspectives of glaciation and glacial melt- 
water. But the fuzzy of spatial and temporal information made the poor operability in the inventory of glacial lakes. In short, it is difficult to determine whether one lake is a glacial lake or not. Theoretically, a glacial lake can be defined as the natural water body formed in the depression by glaciation since the LGM. However, the controversy of glacial coverage area in the LGM and researches' knowledge deficiency of Quaternary glaciology also caused difficulties of identifying glacial lakes based on theoretical concept of glacial lake. On the consideration of the interest of glacial lakes' studies, an alternative definition of glacial lake was proposed, i.e. glacial lake could be defined as the natural water mainly supplied by modern glacial meltwater or formed in glacier moraine's depression. Meanwhile, a complete classification system of glacial lake was proposed based on its formation mechanism, topographic feature and geographical position. Glacial lakes were classified as 6 classes and 8 subclasses: glacial erosion lake (including cirque lake, glacial valley lake and other glacial erosion lake), moraine-dammed lake (including end moraine-dammed lake, lateral moraine-dammed lake and moraine thaw lake), ice-blocked lake (including advancing glacier-blocked lake and other glacier-blocked lake), supraglacial lake, subglacial lake and other glacial lake.

Although this paper attempted to provide the features or quantitative indices for identifying different types of glacial lakes using satellite remote sensing images, and emphasized that the existence of modern glaciers was the primary basis for distinguishing a glacial lake, there were still some problems in the inventory of glacial lakes. When glaciers previously existed in the First Chinese Glacier Inventory and there were glacial lakes in the downstream, if these glaciers disappeared in the Second Chinese Glacier Inventory, did these lakes belong to glacial lakes? So it is very important to ensure the consistency of subject. In addition, the quantitative indices proposed for identifying some types of glacial lakes were derived from the typical glacial lakes, and their representativeness needs to be further studied.

\section{References}

Björnsson H, 2003. Subglacial lakes and jökulhlaups in Iceland. Global \& Planetary Change, 35(3/4): $255-271$.

Cao X C, Liu Z Z, Li W S, 2016. Glacial lake mapping and analysis of the potentially dangerous glacial lakes before Nepal 425 Earthquake in 2015. Journal of Glaciology and Geocryology, 38(3): 573-583. (in Chinese)

Carey M, 2005. Living and dying with glaciers: People's historical vulnerability to avalanches and outburst floods in Peru. Global \& Planetary Change, 47(2-4): 122-134.

Cenderelli D A, Wohl E E, 2001. Peak discharge estimates of glacial-lake outburst floods and "normal" climatic floods in the Mount Everest region, Nepal. Geomorphology, 40(1): 57-90.

Chen C, Zheng J H, Liu Y Q et al., 2015. The response of glacial lakes in the Altay Mountains of China to climate change during 1992-2003. Geographical Research, 34(2): 270-284. (in Chinese)

Chen Y N, Xu C C, Chen Y P et al., 2010. Response of glacial-lake outburst floods to climate change in the Yarkant River basin on northern slope of Karakoram Mountains, China. Quaternary International, 226(1/2): 75-81.

Clague J J, Evans S G, 2000. A review of catastrophic drainage of moraine-dammed lakes in British Columbia. Quaternary Science Reviews, 19(17/18): 1763-1783.

Cui P, Chen R, Xiang L Z et al., 2014. Risk analysis of mountain hazards in Tibetan Plateau under global warming. Progressus Inquisitiones De Mutatione Climatis, 10(2): 103-109. (in Chinese)

Ding Y J, Liu S Y, Ye B S et al., 2006. Climatic implications on variations of lakes in the cold and arid regions of China during the recent 50 years. Journal of Glaciology and Geocryology, 28(5): 623-632. (in Chinese) 
Emmer A, Merkl S, Mergili M, 2015. Spatiotemporal patterns of high-mountain lakes and related hazards in western Austria. Geomorphology, 246: 602-616.

Engel Z, Sobr M, Yerokhin S A, 2012. Changes of Petrov Glacier and its proglacial lake in the Akshiirak massif, central Tien Shan, since 1977. Journal of Glaciology, 58(208): 388-398.

Fujita K, Suzuki R, Nuimura T et al., 2008. Performance of ASTER and SRTM DEMs, and their potential for assessing glacial lakes in the Lunana region, Bhutan Himalaya. Journal of Glaciology, 54(185): 220-228.

Gao X, Wu L Z, Pradeep K M, 2015. Analysis of the characteristics of glacial lake variation in the Koshi River basin, the Himalayas based on RS and GIS. Journal of Glaciology and Geocryology, 37(3): 557-569. (in Chinese)

Huggel C, Kääb A, Haeberli W et al., 2002. Remote sensing based assessment of hazards from glacier lake outbursts: A case study in the Swiss Alps. Canadian Geotechnical Journal, 39(2): 316-330.

Institute of Mountain Hazards and Environment, the Chinese Academy of Sciences and Water Conservancy Ministry, the Traffic Department of the Tibet Autonomous Region, 1999. Debris Flow and Environment in Tibet. Chengdu: Sichuan University Publishing House.

Janský B, Šobr M, Engel Z, 2010. Outburst flood hazard: Case studies from the Tien-Shan Mountains, Kyrgyzstan. Limnologica - Ecology and Management of Inland Waters, 40(4): 358-364.

Kargel J S, Leonard G J, Shugar D H et al., 2016. Geomorphic and geologic controls of geohazards induced by Nepal's 2015 Gorkha earthquake. Science, 351(6269): aac8353. DOI: 10.1126/science.aac8353.

Le M H, Tang C, Zhang D D et al., 2014. Logistic regression model-based approach for predicting the hazard of glacial lake outburst in Tibet. Journal of Natural Disasters, 23(5): 177-184. (in Chinese)

Li J L, Sheng Y W, Luo J C, 2011. Automatic extraction of Himalayan glacial lakes with remote sensing. Journal of Remote Sensing, 15(1): 29-35. (in Chinese)

Liao S F, Wang X, Xie Z C et al., 2015. Changes of glacial lakes in different watersheds of Chinese Himalaya during the last four decades. Journal of Natural Resources, 30(2): 293-303. (in Chinese)

Liu C L, Tong L Q, Qi S W et al., 2016. Remote sensing investigation and influence factor analysis of glacier lake outburst potential in the Himalayas. Remote Sensing for Land and Resources, 28(3): 110-115. (in Chinese)

Liu J, Cheng Z, Su P, 2014. The relationship between air temperature fluctuation and glacial lake outburst floods in Tibet, China. Quaternary International, 321(2): 78-87.

Liu S Y, Cheng G D, Liu J S, 1998. Jokulhlaup characteristics of the Lake Mertzbakher in the Tianshan Mountains and its relation to climate change. Journal of Glaciology and Geocryology, 20(1): 30-35. (in Chinese)

Liu X C, Xiao C D, 2011. Preliminary study of the Jiemayangzong Glacier and lake variations in the source regions of the Yarlung Zangbo River in 1974 - 2010. Journal of Glaciology and Geocryology, 33(3): $488-496$. (in Chinese)

Ma R H, Yang G S, Duan H T et al., 2011. China's lakes at present: Number, area and spatial distribution. Science China Earth Sciences, 41(3): 394-401. (in Chinese)

O'Connor J E, Costa J E, 1993. Geologic and hydrologic hazards in glacierized basins in North America resulting from 19th and 20th century global warming. Natural Hazards, 8(2): 121-140.

Pradeep P K, Bajracharya S R, Joshi S P, 2001. Inventory of Glaciers, Glacial Lakes and Glacial Lake Outburst Floods. Monitoring and Early Warning Systems in the Hindu Kush-Himalayan Region: Nepal. Kathmandu: International Centre for Integrated Mountain Development.

Qin D H, Yao T D, Ding Y J et al., 2016. Glossary of Cryosphere Science. Beijing: China Meteorological Press.

Richardson S D, Reynolds J M, 2000. An overview of glacial hazards in the Himalayas. Quaternary International, 65/66: 31-47.

Shen Y P, Wang G Y, Ding Y J et al., 2009. Changes in Merzbacher Lake of Inylchek Glacier and glacial flash floods in Aksu River basin, Tianshan during the period of 1903-2009. Journal of Glaciology and Geocryology, 31(6): 993-1002. (in Chinese)

Song C, Sheng Y, Ke L et al., 2016. Glacial lake evolution in the southeastern Tibetan Plateau and the cause of rapid expansion of proglacial lakes linked to glacial-hydrogeomorphic processes. Journal of Hydrology, 540: 504-514. 
Song C, Sheng Y, Wang J et al., 2017. Heterogeneous glacial lake changes and links of lake expansions to the rapid thinning of adjacent glacier termini in the Himalayas. Geomorphology, 280: 30-38.

Stokes C R, Popovnin V, Aleynikov A et al., 2007. Recent glacier retreat in the Caucasus Mountains, Russia, and associated increase in supraglacial debris cover and supra-/proglacial lake development. Annals of Glaciology, 46(1): 195-203.

Sun M P, Liu S Y, Yao X J et al., 2014. The cause and potential hazard of glacial lake outburst flood occurred on July 5, 2013 in Jiali county, Tibet. Journal of Glaciology and Geocryology, 36(1): 158-165. (in Chinese)

Tang S G, Liu F X, Zhao Z Y, 2014. Discuss on the temporal and spatial distribution characteristics and impact factors of the eastern Nyainqentanglha Mountain glacier lakes in Tibet. Science \& Technology Information, 12(16): 35-36. (in Chinese)

Wang D, Liu J S, Hu L J et al., 2009. Monitoring and analyzing the glacier lake outburst floods and glacier variation in the upper Yarkant River, Karakoram. Journal of Glaciology and Geocryology, 31(5): 808-814. (in Chinese)

Wang S, Zhang T, 2014. Spatial change detection of glacial lakes in the Koshi River Basin, the Central Himalayas. Environmental Earth Sciences, 72(11): 4381-4391.

Wang W, Yao T, Yang W et al., 2012. Methods for assessing regional glacial lake variation and hazard in the southeastern Tibetan Plateau: a case study from the Boshula mountain range, China. Environmental Earth Sciences, 67(5): 1441-1450.

Wang X, Ding Y, Liu S et al., 2013. Changes of glacial lakes and implications in Tian Shan, central Asia, based on remote sensing data from 1990 to 2010. Environmental Research Letters, 8(4): 575-591.

Wang X, Liu Q, Liu S et al., 2016. Heterogeneity of glacial lake expansion and its contrasting signals with climate change in Tarim Basin, Central Asia. Environmental Earth Sciences, 75(8): 1-11.

Wang X, Liu S Y, Ding Y J, 2016. Study on Evaluation Method and Application of Glacial Lake Outburst Flood in Chinese Himalayan Region. Beijing: Science Press. (in Chinese)

Wang X, Liu S Y, Yao X J et al., 2010. Glacier lake investigation and inventory in the Chinese Himalayas based on the remote sensing data. Acta Geographica Sinica, 65(1): 29-36. (in Chinese)

Wang X, Wu K P, Jiang L H et al., 2013. Wide expansion of glacial lakes in Tianshan Mountains during 1990-2010. Acta Geographica Sinica, 68(7): 983-993. (in Chinese)

Wang Y, Li J L, Li C C et al., 2016. Spatialtemporal change of glacial lakes in the Biezhentao Mountain and its response to climate change. Arid Zone Research, 33(2): 299-307. (in Chinese)

Wingham D J, Siegert M J, Shepherd A et al., 2006. Rapid discharge connects Antarctic subglacial lakes. Nature, 440(7087): 1033-1036.

Wortmann M, Krysanova V, Kundzewicz Z W et al., 2014. Assessing the influence of the Merzbacher Lake outburst floods on discharge using the hydrological model SWIM in the Aksu headwaters, Kyrgyzstan/NW China. Hydrological Process, 28(26): 6337-6350.

Wu L, Li X, Liu S et al., 2011. Remote sensing based glacial lake inventory in the Hindu Kush-Himalaya region. International Conference on Remote Sensing, 1451-1454.

Yao X J, Liu S Y, Li L et al., 2014. Spatial-temporal characteristics of lake area variations in Hoh Xil region from 1970 to 2011. Journal of Geographical Sciences, 24(4): 689-702.

Yao X J, Liu S Y, Sun M P et al., 2014. Study on the glacial lake outburst flood events in Tibet since the 20th century. Journal of Natural Resources, 29(8): 1377-1390. (in Chinese)

Yi C L, Cui Z J, 1994. Classification and sedimentary types of glacial lakes in the Halasi River catchment, the Altay Mountains, Xinjiang. Oceanologia et Limnologia Sinica, 25(5): 477-485. (in Chinese)

Zhang G, Yao T, Xie H et al., 2015. An inventory of glacial lakes in the Third Pole region and their changes in response to global warming. Global \& Planetary Change, 131: 148-157.

Zhang X S, Li N J, You X Y et al., 1989. Jokulhlaups in the Yarkant River, Xinjiang. Science in China Series B, 11: 1197-1204. (in Chinese) 